\title{
Does IFRS Adoption Improve Financial Reporting Quality? Evidence from Commercial Banks of Ethiopia
}

\author{
Goshu Desalegn \\ Lecturer@ the Department of Accounting and Finance. \\ Kotobe Metropolitan Uiversity: Addis Ababa, Ethiopia
}

\begin{abstract}
The main purpose of this study is to analyze International Financial Reporting Standard (IFRS) adoption and quality of financial reporting by commercial banks in Ethiopia using qualitative characteristics of accounting information such as: Relevance, Understandability, Comparability, and Faith Representation. The study used the perceptions of preparers of banks financial reports (accounting \& finance officer, finance managers as well as IFRS implementation team members) to analyze about IFRS adoption in commercial banks. The study adopted mixed research approach and descriptive research design. More specifically, the study used purposive sampling technique to collect a data; the data was collected through primary and secondary source of data. The primary data was collected through questionnaire and secondary data was from different source of documents. The data was analyzed using descriptive statistics. The finding of the study reveals that; the quality of financial report which is measured through (relevance, understandability, comparability and faith representation) was improved after adoption of international financial reporting standards.
\end{abstract}

Keywords: IFRS adoption, financial reporting quality, relevance, understandability, comparability, faith representation, commercial bank, Ethiopia.

DOI: $10.7176 /$ RJFA/11-7-03

Publication date: April $30^{\text {th }} 2020$

\section{Introduction}

Accounting Standard is a rule or sets of rules, which prescribes the methods by which financial records should be prepared and presented. Hence, IFRSs are a set of international accounting standards stating and reporting rules that defines how business transactions should be recorded and reported and what information a company should disclose in its financial statements. Unlike the US GAAP which rely on rule based and historical cost, IFRS as a new standard focus on principle based and fair value. The proponents of IFRS argue that this standard provides more value relevance than the old one (Ball et al., 2003). IFRSs are issued by the international accounting standards board (IASB), and they specify exactly how accountants must maintain and report their accounts. It is the most accepted and widely followed accounting standards all over the world. Globalization of capital markets requires a unified global accounting, reporting and disclosure set of standards. As noted in (Surianti and Yadiati 2017). Accounting is a powerful source of information and it is not just about processing data, aimed to mark the presence and movement of the elements of previous and the ability to respond to the needs for control. As the data set the entire accounting system set up on a bunch of goals principles and standard. IASB states that the general purpose financial reporting (communication of financial information to user) is to provide financial information about the entity reported that are useful for potential investors, lenders other creditors in making decisions about providing resources to the entity. These decisions including buying, selling or holding equity and debt instruments and providing or settlement loans and other forms of credit. So that, the decisions taken are accurate, then the accounting information generated accounting information to be useful, information that meets the needs of the user. To be useful, the accounting information (financial) must be relevant and it aptly describes what is meant to be the described (faithfully representation). The usefulness of. Financial information will increase if the information is comparability, verifiable, timely and understandably as increasing volume of cross borders capital flows and the growing number of FDI via mergers and acquisition in globalization area, the need for harmonization of different practice in accounting and the acceptance of worldwide standard has raised. The worldwide standard is IFRS. Although there has been series of contentions as regarding the impacts this standard on the quality of financial report, but this study will provide a clear understanding of their relationship. Currently, global economy accounting standardization has become a central issue for governments, capital providers, international organizations and enforcement agencies. Ethiopia is being one of the global players, movement to IFRS will enable Ethiopian entities to have access to international capital markets. IFRS is expected to lower the cost of raising the funds, reduce accountant fees and enable faster access to all major capital markets it also facilitates companies to set targets and milestones based on a global business environment (Rakesh \&Shilpa, 2013). Implementing high quality International Financial Reporting Standards (IFRS) is critical to meeting and sustaining Ethiopia's economic growth potential. IFRS provides international investors with a brand of trust in the quality of financial reporting. That trust in financial reporting is essential if investors are to be encouraged to step in to promote continued economic growth. IFRS will also have a profound impact on the country's growth potential because 
nationally supported IFRS will increase stability, stewardship, accountability and transparency both at institutional and government level. It will also increase the general level of professional education of accountants and standards setting bodies and improve their policies and decision making. It will lay the foundation to the much-needed domestic capital market to mobilize financial resources for long-term investment. In general, implementation of IFRS contributes to Government efforts of improving good governance and reducing the level of corruption and rent seeking behaviors. All of these will in turn help to remove major impediments to growth that are common in emerging economies like Ethiopia (AABE, 2015). Hence, this study set out to examine whether the adoption of IFRS in Ethiopia improve the quality of financial reporting with regarding to commercial banks. The study specifically tests whether there is higher value relevance in the adoption period as opposed to the pre adoption period. Therefore, the general objective of this study is to assess the International Financial Reporting Standards (IFRS) adoption and financial reporting quality of commercial banks in Ethiopia.

\section{Literature review}

The literature shows the existence of different theories related to the financial reporting quality and concept of International Financial Reporting Standard. These theories include positive accounting theory, normative accounting theory, Conservative method theory, stakeholder theory, agency theory and stewardship theory.

\section{Positive accounting theory (PAT)}

The Positive accounting theory is based on the inconsistency between the interests of shareholders (but also other users of financial statements) and those of managers. According to this theory, outside users of accounting information always wish to have relevant, reliable and comparable financial statement presenting a true and fair view of the financial position and performance of firm.

\section{Normative accounting Theory (NAT)}

Normative Accounting Theory is an accounting theory which play an important role in the accounting systems used today by finance managers and investors. Normative accounting theory most commonly found in a company's business or marketing plan takes a subjective approach. The practices this theory is a form of value judgment that can introduce subjective morality into accounting. According to (Kipkirui 2014) Normative theories of accounting are not necessarily based on observation and therefore cannot be evaluated on whether they reflect actual accounting practice or not.

\section{Agency theory}

Agency theory is the relationship between the principals and agents where shareholders are the principals and the company executives and managers are the agents. In agency theory, shareholders expect the agents to act and make decisions in the principal's interest while on the contrary, the agent may not necessarily make decisions in the best interests of the principals. It focuses on reciprocity(self-interest), and its primary objective is to minimize agency cost. It is an individualistic model with opportunistic behavior (Aigienohuwa \& Ofuan 2018)

\section{Stakeholder theory}

Stakeholders are defined as individual or groups with legitimate interests in procedural and substantive aspects of the activity of the organization. This shows that the stakeholder theory objective viewpoints are to satisfy the interests of each group (the principal and the agent) and not as a mean to achieve other goal (Alayemi \&Morohunfola 2017). This legitimacy is established through the existence of an exchange relationship. Stakeholders include stockholders, creditors, managers, employees, customers, suppliers, local communities and the general public (Ezeagba \& Charles 2017).

\section{Stewardship theory}

A steward is defined as someone who protects and takes care of the needs of others. Under the stewardship theory, company executives protect the interests of the owners or shareholders and make decisions on their behalf. Their sole objective is to create and maintain a successful organization so the shareholders prosper (Anita 2018). The stewardship theory of governance has a clear objective of shareholder satisfaction. having a single leader creates one channel to communicate business needs to the shareholders and the shareholders' needs to the business. This also avoids confusion as who is in charge when a company needs to weather a storm. Stewardship implies taking personal responsibility for organizational action that affect the welfare of stakeholders inside and outside the corporation. Leaders model stewardship by demonstrating a personal responsibility for organizational actions, by taking into account a concern for balancing their self-interest with internal stakeholder interest, balancing their self-interest with stockholder interests and balancing the interest of stakeholders inside and outside the organization when making decisions (Morela 2007). 


\section{Conservative method theory (CMT)}

The principle of conservatism is a pervasive concept in modern accounting theory, and is probably a carryover from the day when banks were the primary users of firms' financial statements. Conservatism reflects the idea that, given two equally likely outcomes, a firm should use the accounting method that results in smaller reported income or smaller reported net assets (Mabruk 2011).As noted in Bernstein, and Subramanyam (2001) the quality of conservatively determined earnings is perceived higher because they are less likely to overstate current and future performance expectations compared with those determined in an aggressive manner". Comiskey (1971) concluded that "The particular set of accounting alternatives can be thought of as adding a unique 'quality dimension' to the earnings. The following section discusses the empirical reviews of the study area.

Yurisandi \& Puspitasari (2015) conducted the study to examine the financial reporting quality before and after IFRS adoption using nice qualitative characteristic measurement. The study used paired sample test to analysis data. the financial reporting quality before the IFRS adoption represented by the period 2009-2010.while the financial reporting quality after the IFRS is represent by the period 2012-2013. The researcher concluded that IFRS adoption increases the quality of financial reporting. The result of the study show that the qualitative characteristics of relevance, understandability and comparability level increased after IFRS adoption.

Abdurazak (2011) have studied the effect of IFRS adoption on quality of accounting reports of small and medium enterprise in Nairobi County. The study applied accounting quality measures; faithful representation, comparability, timeliness, understandability and value relevance to find out whether the adoption of IFRS has led to improvements in accounting reports quality of SME in Nairobi County. The collected data was analyzed using qualitative approaches. The study used stratified random sampling whereby enterprises were grouped into two, the small enterprise and medium enterprises. The finding of the study reveals that; adoption of international financial reporting standard improves the financial reporting quality of the enterprises.

Maryjane (2016) examined whether mandatory adoption of IFRS is associated with improvement in accounting quality of banks listed on the Nigerian Stock Exchange (NSE). The resulting of the study show that adoption of IFRS reducing the quality of accounting amount disclosed in the financial statements. The study suggested that universal adoption of IFRS is an essential determinant of financial reporting quality, as many firms across different countries will be using the same set of accounting standard in preparing their financial statements.

Melese (2016) conducted a study to examine adoption, challenge and perception of IFRS on the quality of financial reporting of financial institution in Addis Ababa, Ethiopia. The study focuses on identifying the impact of adopting IFRS on the quality of financial reporting, examining the challenges and recognizing the benefits of adopting IFRS in financial institution. The study used both qualitative and quantitative approach by taking a sample of 32 out of 35 private banks and insurances companies registered under National Bank of Ethiopia. The study uses both primary and secondary data source collected through questionnaire and document review. The study reveals that high implementation costs, the complexity of financial reporting, lack of IFRS implementation agent, lack of IFRS implementation guidance, lack of availability of competent specialists, high level training requirement, less familiarity with the IT challenges in handling the implementation of IFRS, lack of proper instructions from regulatory bodies, and problem with IFRS implementation proper plan and absence of commitment \& proper plan of financial institutions to implement IFRS and requirements of the existing Tax law amendment are the challenges.

\section{Research methodology}

This study adopted a mixed research approach and descrptive research design in order to investigate the effect of Inernational financial reporting standards on financial reporting quality in Ethiopian banking industry.

Target Population, Sampling techniques and sample size.

The study population included all the seventeen (17) commercial banks which are registered by National bank of Ethiopia during the field study period. In this study, the sampling technique used was purposive sampling technique; which purposively selects 7 banks from the total population of the study based on the fact that they were among the first set of banks that transited from GAAP to IFRS. Additionally, since the selected banks have published IFRS based financial reporting; it was the main criteria for selecting them from total population of the study.

\section{Data Analysis and Discussion of the Result}

The researcher has distributed 160 questionnaires to respondents; which includes two types of questionnaires, the first questionnaire was distributed to analyze the quality of financial information before adoption of international financial reporting standard. And, the second one was distributed to analyze the quality of financial information after adoption of international financial reporting standard. So, the overall returned questionnaire was 140 questionnaires $(87.5 \%)$ and the rest of respondents (12.5\%) did not return the questionnaire 
Table 4.1: Descriptive Statistics for Post-IFRS Adoption

\begin{tabular}{|c|c|c|c|c|c|}
\hline & $\mathrm{N}$ & Minimum & Maximum & Mean & Std. Deviation \\
\hline Relevance & 140 & 3.50 & 4.38 & 3.9821 & .30382 \\
Faithful & 140 & 4.00 & 5.00 & 4.5510 & .34722 \\
Usefulness & 140 & 4.00 & 5.00 & 4.5286 & .35480 \\
Comparability & 140 & 3.50 & 4.38 & 4.0402 & .27249 \\
Valid N (listwise) & 140 & & & & \\
\hline
\end{tabular}

Source: SPPS output 20.

Table 4.2: Descriptive Statistics for Pre- IFRS Adoption

\begin{tabular}{|l|r|r|r|r|r|}
\hline & $\mathrm{N}$ & Minimum & Maximum & \multicolumn{1}{|c|}{ Mean } & Std. Deviation \\
\hline Relevance & 140 & 1.00 & 3.00 & 1.9384 & .47380 \\
Faithful & 140 & 1.00 & 3.00 & 1.9152 & .48754 \\
Comprability & 140 & 1.00 & 3.00 & 1.9304 & .46075 \\
Usefulness & 140 & 1.00 & 3.00 & 1.9857 & .46459 \\
Valid N (listwise) & 140 & & & \\
\hline
\end{tabular}

Source: SPPS output 20.

Note: According to Best (1977), the decision rules used in the analysis of descriptive stastics is made by comparing the average mean.

If the average mean is less than 3 , it is considered as low, if the average mean is equal to 3 , it is considered as medium and average mean greater than 3 is considered as high (Best and khan1995).

\section{Relevance Value}

From the above descriptive analysis; some one can understand that; the relevance value of financial information has a mean value of 4 which indicates that the value relevance has improved after adoption of International financial reporting standards. While on the other hand, the mean value of relevance before adoption of international financial reporting stardads is less than 3 (1.9).

Graph 4.1. Respondents response rate on the value relevance.

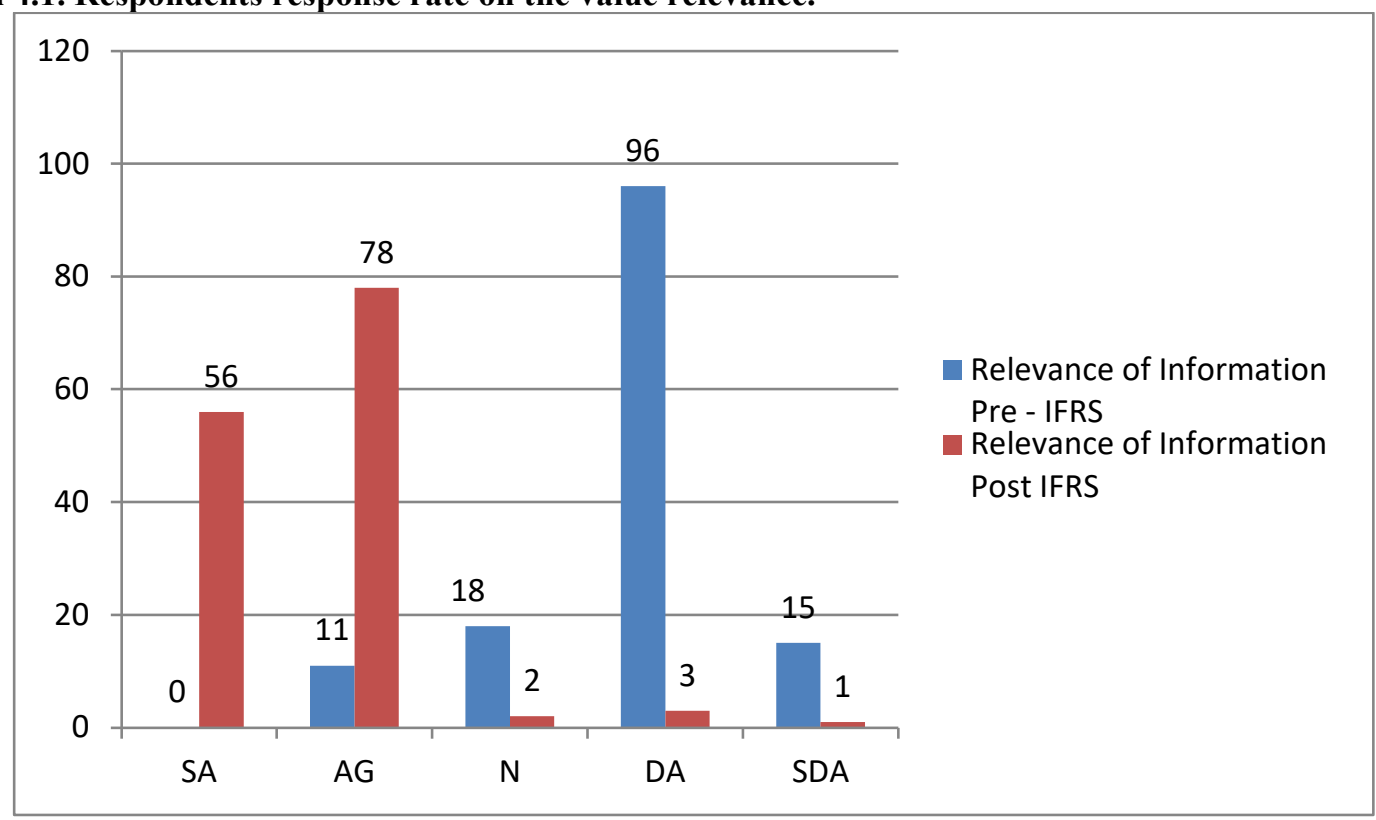

Source: Primary data

The adoption of international financial reporting standard improves the relevance of financial information when it is compared to pre adoption quality of financial information's. This can be evidenced from the rate of responses responded with regard to the effect of adopting international financial reporting standards in improving financial reporting quality of accounting information's. The overall response rate shows that; the adoption of international financial reporting standard improves the relevance of financial information by greater frequency of 123 response rate. This implies that; the relevance of financial information is improved with adoption of international financial reporting standards. The finding of this study is consistency with the finding established by (Musa, 2015). 


\section{Understandability}

The result of descriptive stastics shows that; the understandability of financial information has a mean value of 4.5 and 2 respectively for both post and pre- Adption of International financial reporting standards. As stated in the above statement, the understability of the financial information has improved after adoption of international inancial reporting standards. Understandability, will increase when information is classified, characterized, and presented clearly and concisely. Understandability is referred to, when the quality of information enables users to comprehend their meaning (IASB, 2008). According to Yurisandi and Puspitasari (2015) understandability of financial reports increased after IFRS adoption at $1 \%$ level of significance.

\section{Graph 4.2.Respondents Response rate with regard to Understandability}

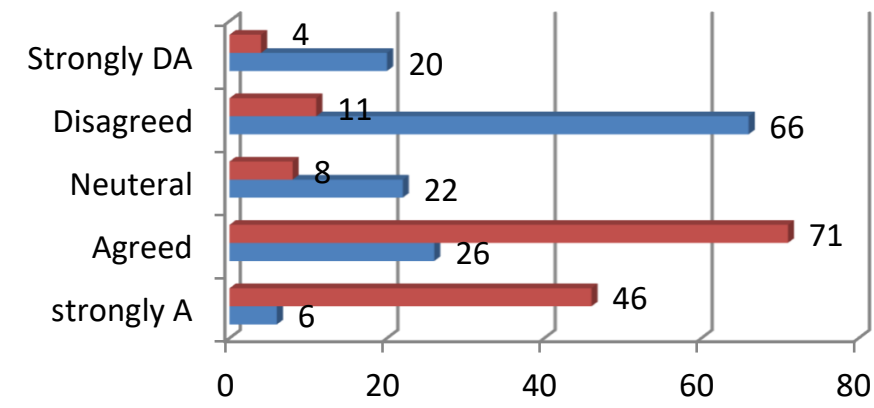

Understandebility of Information Post-IFRS

Understability of Information pre-IFRS

\section{Source: primary data}

As Cleary indicated in the above graph 4.2; Understandability of financial information pre and post international financial reporting standards was analyzed. The result of data collected shows that adoption of IFRS improved the understandability of financial information and this can be evidenced from overall response rate of respondents. The data collected revealed that 117 respondents were agreed on the adoption of international financial reporting standard in approving the understandability of financial information's. On the other hand, 32 of respondents were agreed that the understandability of financial information were better pre adoption of international financial reporting standard. In this case, only 85 respondents show their support for adoption of international financial reporting standard in improving overall understandability of the financial information. From this, it is possible to conclude that; the adoption of international financial reporting standard improves overall understandability of financial information.

\section{Comparability}

Comparability can refer to the similarity in inputs of a reporting system (i.e., accounting methods, transaction structures, business model), the similarity in recognized accounting numbers (reported earnings or assets and liabilities), or the similarity in reporting structures and disclosures. As highlited in the above descriptive statsictics the mean value of comparability is 4 and 1.9 respectively for both post and pre-adoption. The implication indicates that the adoption of international financial reporting standards improves the comparability of financial information. The following graph 4.3 shows overall relationship between comparability and adoption of IFRS.

Graph 4.3: Respondents response rate on comparability of financial report.

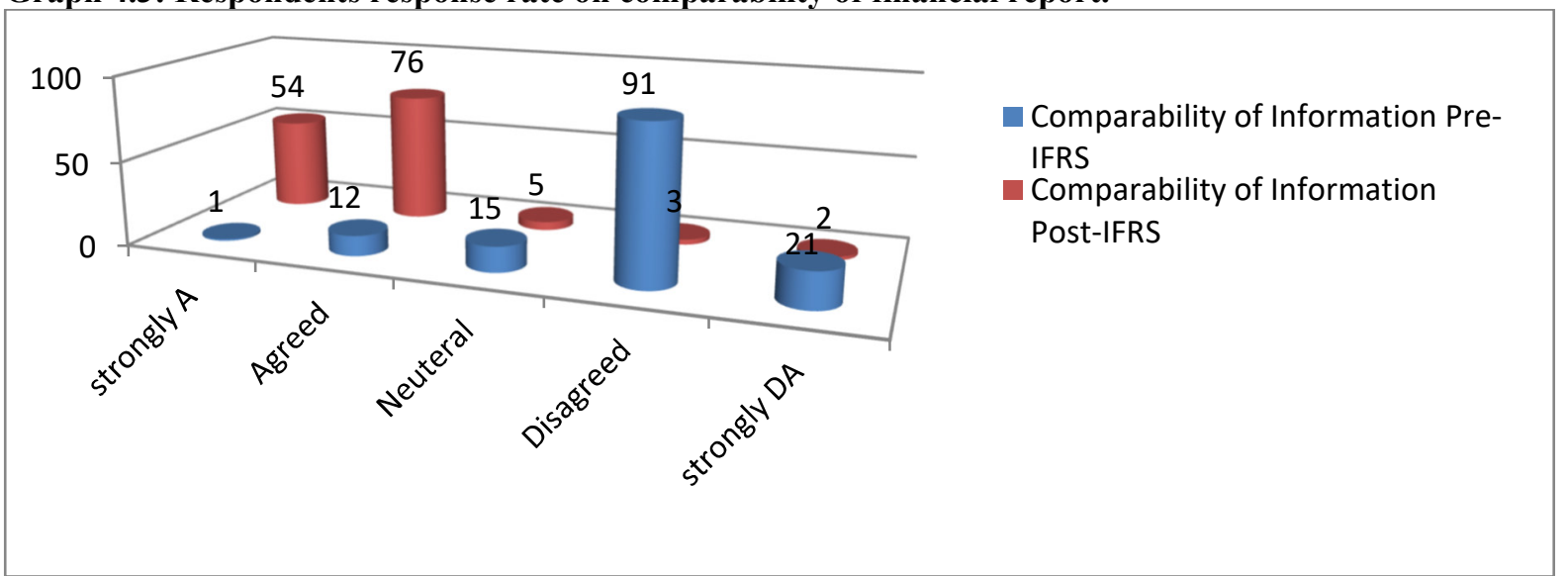

Source: primary data.

In the above graph 4.3 , the overall comparability of financial information was compered as pre and post adoption of international financial reporting standards. The result of data collected shows that; the comparability of financial information was improved as adoption of international financial reporting standard in commercial 
banks in Ethiopia. 130 numbers of respondents were agreed on improvement of comparability of financial statement as adoption of international financial reporting standards. While, 13 respondents were agreed that; the comparability of financial information was better pre adoption of international financial reporting standards; so, based on the number of data collected and observations made by researcher, it is possible to concluded that; the comparability of financial information is improved after adoption of international financial reporting standards. The evidence of data collected shows that; adopting international financial reporting standard improves the comparability of financial information was supported by greater response rate of 117 .

\section{Faithful Representation}

The adoption of IFRS is an issue of a global standard among various countries of the world due to the quest for high quality financial information. Providing high quality financial reporting information is important because it will positively influence capital providers and other stakeholders in making investment, credit and similar resource allocation decisions enhancing overall market efficiency (IASB, 2013). As highlited in the above descriptive statsictics the mean value of faithful representation is 4.5 and 1.9 respectively for both post and pre-adoption. The implication is that; adoption of international financial reporting standard improves the faithful represenatation of the companies financial information. The respondents response rate on faithful representation and financial reporting standard is summarized in the following graphs.

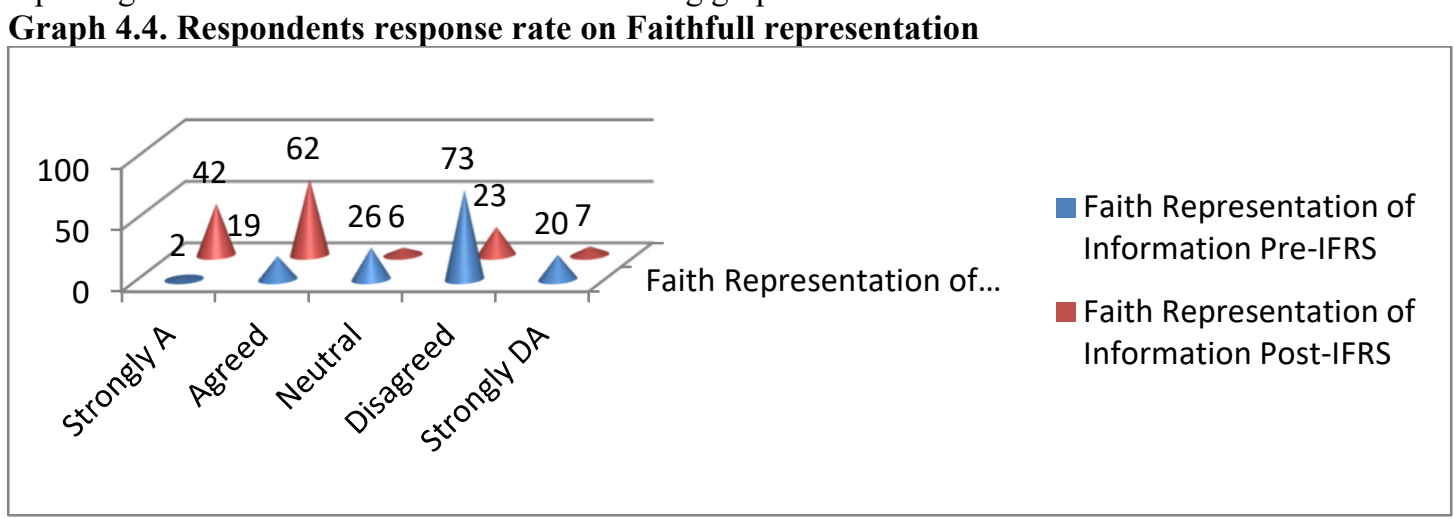

Source: primary data.

Faithfull representation is another proxy which measures financial quality of the information's. The data collected with this regard reveals that; the faithfulness of financial information was improved after adoption of international financial reporting standards. From the data collected 104 numbers of respondents were agreed on improvement of Faithfull representation of financial information's after adoption of international financial reporting standards. While on the other hand, 21 numbers of respondents were agreed that; the faithfulness of financial information was better before adoption of international financial reporting standards. The number of respondents those replied on improving of faithfulness of financial information after implementation of IFRS was greater by a frequency of 83 . From this, the researcher concluded that adoption of international financial reporting standard improves the Faithfull representation of the financial information's.

\section{Conclusion}

The objective of this study was to analyze the IFRS adoption and financial reporting quality; by taking an evidence from banking industry in Ethiopia. For this purpose this study was investigated the effects of the IFRS adoption on value relevance, understandability, comparability and faith representation of accounting information in Ethiopian commercial banks. The research indicates financial reporting quality after and before adoption of IFRS of commercial banks. To achieve the objective of the study, the study adopted descriptive research design and mixed research approach. Furthermore, purposive sampling techniques were used to select a number of sampled banks from the total population of the banking industry. More specifically, primary and secondary data was used to analyze IFRS adoption and financial reporting quality; the primary data was collected through questionnaire and observation, the questionnaire was prepared in two different formats. The first format contains the question which indicates financial reporting quality before adoption of international financial reporting standard and the second format includes the question which indicates the quality of financial reporting after adoption of international financial reporting standard. In order to achieve the objective of the study 160 questionaries' was distributed to respondents and 140 of them were returned the questionnaire and the remaining 20 was unreturned.

The finding of the study reveals that: there has been an increase in the value relevance, understandability, comparability and faith representation of accounting information after adoption of IFRS. Premise on the findings of the study, it can be concluded that adoption of IFRS has notable influence on financial reporting quality of commercial banks in Ethiopia. 
The finding of the study further shows that; the adoption of international financial reporting standard improves qualitative characteristic such as value relevance, understandability, comparability and faith representation when it is compared to pre adoption of international financial reporting standard.

\section{REFERENCES}

Accounting and Audit Board of Ethiopia (AABE) Five Years Strategic Plan 2015

AICPA, Www.IFRS.com: IFRS FAQs. AICPA/ Www.IFRS.com- International Financial Reporting Standards Resources, Web. Retrieved, 12Feb. 2012 http://ifrs.com/ifrs_faqs.html

Andre P., Filip A., Paugam L. (2013), Impact of Mandatory IFRS Adoption on Conditional Conservatism in Europe, working paper, ESSEC Business School, available on www.ssrn.com;

Ball, R., Robin, A., \& Wu, S. (2003). Incentives Versus Standards: Properties of Accounting Income in Four East Asian Countries. Journal of Accounting and Economics 36, 235 - 270

Ball R., Li X., Shivakumar L. (2013), Contractibility of Financial Statement Information Prepared Under IFRS: Evidence from Debt Contracts, working paper, available on www.ssrn.com;

Barth, M., Landsman, W.R. \& Lang, M. (2008). International Accounting Standards and accounting quality. Journal of Accounting Research 46, 467-49

Bartov, E. \& Mohanram, P. (2004). Private information, earnings manipulations, and executive stock-option exercises. The Accounting Review, 79(4), 889-1010

Barth, M., Beaver, W. \& Landsman, W. (2001). The relevance of the value relevance literature for financial accounting standard setting: another view. Journal of Accounting and Economics, 31, 77-10

Christensen, H. B., Lee, E., Walker, M. (2008), Incentives or Standards: What Determines Accounting Quality Changes around IFRS Adoption? Working paper, Manchester Business School

Chen, F., Hope, O.K., Li, Q. \& Wang, X. (2011). Financial reporting quality and investment efficiency of private firms in emerging markets. The Accounting Review, 86(4), 1255-1288.

Commercial Ethiopian Banks, (2017/18), Annual Report, Addis Ababa, Ethiopia

Courtis, J. (1995). Readability of annual reports: Western versus Asian evidence. Accounting, Auditing and Accountability Journal, 8(2), 4-17

Creswell, JW. (2009), 'Editorial: Mapping the field of mixed methods research`, Journals of Mixed Methods Research Vol.3, No.95, pp.95-109

Creswell, W.J. (2003), Research Design: Qualitative, Quantitative and Mixed approaches, 2nd ed., New Delhi: Sage.

Hirst, D., Hopkins, P. \& Wahlen, J. (2004). Fair Values, Income Measurement, and Bank Analysts' Risk and Valuation Judgments. The Accounting Review, 79(2), 453-472

Herath, S. K. \&Albarqi (2017). Financial Reporting Quality: A Literature Review. International Journal of Business Management and Commerce: 2(2),

Holthausen, R. W. (2009). Accounting Standards, Financial Reporting Outcomes, and Enforcement. Journal of Accounting Research, 47(2), 447-458.

International Accounting Standards Board [IASB]. (2010). The Conceptual Framework for Financial Reporting. Retrieved from http://eifrs.iasb.org/eifrs/bnstandards/en/ framework.pdf

IASB. (2008, 2013). Exposure draft on an improved conceptual framework for financial reporting: The objective of financial reporting and qualitative characteristics of decision-useful financial reporting information. London

Iyoha, F.o. and Faboyede (2011), Adopting International Financial Reporting Standards(IFRS) a focus on Nigeria, International Journal of Research in Commerce and management Volume Number 2, Issue Number 1 Page $35-40$

Juniarti1, Ferbiana Helena, Karina Novitasari, and Wenny Tjamdinata (2018)

Jonas, G. \& Blanchet, J. (2000). Assessing Quality of Financial Reporting. Accounting Horizons, 14(3), 353-363. 